DOI: 10.20472/IAC.2018.036.015

SHEHU HASHIMU

Umaru Ali Shinkafi Polytechnic Sokoto, Nigeria

\title{
AFRICAN MIGRATION TO EUROPE AND THE EMERGENCE OF MODERN SLAVERY AFRICA: WHO IS TO BLAME? NIGERIA IN PERSPECTIVES
}

\begin{abstract}
:
Ever since the beginning of exploitation, penetration and colonialism of African continent by the European capitalists in the 17th and 18th centuries, the history of African perspectives changed from peaceful direction to a conflicting one. This is because institutions such economic, traditional ruling system, cultural heritage, tradition of excellence as well as the large population of the continent were either destroyed or had their existence shaped by this evil of colonization. For those who read African history they were aware of the African underdevelopment architected by colonialism. At the end of the day African's leadership was left on the hands of indigenous people without a blue print to guide the new leadership. It's against this background that this paper examines the current situation of this massive migration to Europe by Africans especially with Nigeria as a reference in perspective. The cause, consequences and who are to blame for this unprecedented event of modern slavery are part of the discussions of the paper. Again, bad governance, corruption coupled with leadership style and European economic policy toward developments in Africa contributed of threat through insecurity immigration. It forms another segment of this paper.
\end{abstract}

\section{Keywords:}

African; Migration; Europe; Slavery; Nigeria 


\section{Historical Background}

Over the past centuries, there existed unknown and un-invaded continent outside and far away from Europe and Asia known as Africa the 'Dark continent' (Rodney, 1972). Historically human civilization had flourished in Africa from the pre-historic times; there had been archaeological discoveries in Africa which confirmed the great antiquity of human civilization in Africa for more than two million years (Afolalu, 2000). For greater record on the antecedent of African historiography, several mighty empires, kingdoms, dynasties and vassal states existed and they have been in contact with the peoples living outside the continent in Europe as well as in Asia respectively. This contact emanated either from trade or other contacts such as by diplomacy or disputes with neighbours beyond Africa's shores in Southern Europe and the Middle East (Ayandele, 1978; Yandaki, 2015).

However, these African powerful states were able to conquer vassal states for territorial expansion and above all were able to repelled any attack by the forces within and outside for territorial defence. In a nut shell, Africa South of the Sahara was very much a closed world of its own which made its own adjustments between rising and falling empires without reference to the state of things in Europe or Asia. From historical perspectives, apart from the Portuguese incursions into Angola in the seventeenth century, the Europeans, Arabs and Indians who traded on Africa's coasts did not venture far beyond their trading ships or forts at any time before the $19^{\text {th }}$ century. This trade with the outsiders remained on the coast until when first Industrial revolutions brought significant change in productions which brought a huge demand of labour who would work in the new industries and these labour demands caused unfortunate circumstances in Africa that is the slave trade. Again, the huge increase of production also caused competition at home markets and as a result led to the struggle for searching new markets and raw materials outside Europe which was in Africa. This rise of industries which led to rapid growth and accelerated economic development intensified the formation of the slave trade across the Atlantic Ocean and final encroachments of African hinter land began (Onwubiko, 1985; Ayandele, 1978).

\section{Slave trade}

Slave trade was a bad omen to African societies. This is because it destroyed many viable institutions that run the affairs of the society which as a result to day Africans are facing the consequences. The emergence of capitalism in Europe coupled with rise of first industrial revolutions (first and second) no doubt gave a consistent demand for the search of labour used in the factories. This issue of labour demand brought about buying African human beings as slaves in large quantities to work in the industries in United State and Europe. It has been discovered that Europeans obtained these slaves in an exchange with the manufactured goods and on the other hand, used ample opportunity exploiting the tribal, divisions and the emergence of class within African societies. The fact was that no accurate statistics or data given the actual number of slaves shipped to Europe from Africa. Some 
figures were estimated at five million, twelve million, fourteen million and more (Rodney, 1972). The truth of the matter is that whether the figures were accurate or not the fact still remains that there cannot be a denial or change that several million Africans were placed on slave ships exported to Europe and West Indies.

Having achieved their economic goals, the colonialists decided to terminate the trade (by abolishing it) and later replaced it with another trade known as 'Legitimate trade' at the expense of African traders and farmers. Legitimate trade replaced trade in human being with other agricultural products such as palm oil, groundnuts, coffee, gum, rubber, and cotton, timber, ivory and indigo and later cocoa. These commodities were in great demand in Europe. Although, it had been argued that, legitimate trade had importance on social, economic and political effects on West Africa. The reasons here was that it brought the new era from selling human beings to exporting of farm products to Europe. It's agreed that Africans began to recover their human dignity and glory which was dehumanized as a result of the slave trade (Onwubiko, 1985; Ryder, 2001). The second argument is that the economy of Africa was boomed because the growing trade attracted large numbers of European firms, traders and companies who operated within the coast of Africa by 1840 . This quest for African produce stimulated African to free, healthy and productive labour within their continent. But the central argument here is that Africa benefited less compared to their European counter parts.

After legitimate trade progressed than the Christian missionaries were introduced to provide western type of education and later the scramble for and partition of West Africa came on board. The partition of West Africa by European powers in the last twenty years of the $19^{\text {th }}$ century is the most important event in its history. This is because it was the culminating event in a series of movements in the $19^{\text {th }}$ century which finally brought West African (and in fact the whole Africa with the exception of Ethiopia and Liberia) under colonial rule. Again, the partition is the genesis of West Africa history in the $20^{\text {th }}$ century, for the European rule of West African states and their struggle to regain their independence which forms the results of the partition (Onwubiko, 1985; Shehu, 2016).

\section{Africa after Independence and Problem Facing the New States}

It is an interesting fact of history that within fifteen years after the end of the Second World War, almost all the modern states of Africa had gained political independence. This radical and phenomenal change was brought about by post-war nationalist activities which compelled the colonial powers to restore to these states the sovereignty they had lost following the partition and introduction of colonial rule. (Joshua, 2003; Shehu, 2016).

Colonialism posed negative economic implications. The fact is that African minerals resources were dug up and shipped away. The best farmlands were acquired, planted with export crops rather than subsistence crops, and these farms were over worked and they partly eroded. The infrastructures claimed to have been provided by colonialism was only 
to serve the purposes of imperialism rather than the local communities where these resources were being tapped. For instance rail lines were provided in order to transport mining raw materials and agricultural products to the ports for shipping them to Europe. The education and skills needed to run the economy were largely limited to the whites while Africans were subjugated. The consequences was that, when colonies attained independence and the whites departed, what remained was an under-educated population with a distorted economic structure and valuable natural resources depleted (Joshua, 2003). There is the notion that imperialism concentrated the accumulation of wealth at the expense of others and it drained economic surpluses from the periphery, one might expect that accumulation in the third world take off once colonialism was over through which is not the reality, because many states in Africa the case is reversed. There seems to be going backward with little new capital accumulating to replace the old colonial infrastructure after independence The fact is that most former colonies are making only slow progress in accumulation, thereby; political independence has not been core all for poor countries (Joshua, 2003; Ake, 2008; Yandaki, 2015).

It has been observed that colonialism certainly created some problems for the newly independent states. One problem is that during the era, the trained and experienced people who could manage the economy such as factory managers, doctors, bankers and so on were limited only to Europeans. Very few African were opportune to study abroad and when they returned the colonialists neglected many of them without any provision for them to work effectively in colonial administrative offices as a result when Europeans left the country after independence, they left a vacuum in technical and administrative skills. The newly independent states were left with the internal rivalries of ethnic groups and for that reason the regions could not afford to implement viable economic plans properly as expected. This is because African states witnessed unprecedented ethic conflict which caused civil wars. Nigeria is a typical reference point; after independence the country was confronted by a civil war, which reversed capital accumulation. The post-colonial states were little more than puppet government in the hands of former colonizers and as a result could not function effectively; instead, corruption and bad governance became worse after independence (Salami, 2000; Shehu, 2016; Joshua, 2003). It is out of this background that the current train of massive migration to Europe evolved.

\section{Migration: The Conceptualization}

Migration within Africa occasioned by the search for better means of livelihood, by conflict between expanding groups over the use of land, by disputes of a family nature, by any sudden development which made life intolerable in a particular place, must have been a common phenomenon over the centuries. Such movements could not only result in the foundation of new settlement or the development of old ones as potential nuclei of states, but could also contribute to the development of states already founded. The central issue of migration admitted by many scholars was economic opportunities for trade or 
employment provoked great movements of people into areas inhabited by other ethnic groups and across boundaries. In some cases this movement was a purely economic response to opportunities for profit, in others it was stimulated by social considerations, such as the desire to escape from the restricting nature of traditional African society and, in yet others it was induced by the policies of the colonial powers (Smith, 1988; Hance, 1970; Jackson, 1964; Crowder, 1978). This conceptualization of migration in the past coupled with historical background of African states before, during and post-colonial era still remain the impetus of the current train of massive migration to Europe.

\section{African Migration to Europe and the Emergence of Modern Slavery Africa}

\section{Nigeria in Perspective}

African migration to Europe has become the current theme of discourse in national and international media and as well as in social media. It became one of the actors in international relations that engaged scholars, industrialist and government in Europe and Africa in particular. It changed the foreign policy of many countries affected by this unprecedented momentum of growing and increased intentions of irregular migration to Europe from Africa in recent year. Because many European countries defied to absorbed this migrants or refugees to have a shelter in their countries.

The causes of this current massive migration to Europe vary from one country to another. But there are many things in common, that is massive unemployment which threatens the survival of young teeming youths in Africa, population pressure, coupled with scarce resources which created difficulties in the struggle for survival is another issue of concern. Other related issues include bad leadership which is dominant in the current trend in states affairs of Africa, lack of accountability and frequent change of economic policies by African leaders; these truncate dividends of democracy in African continent. There is absence of true liberal democracy because some leaders in Africa were in power for many decades and prefer to remain in power until they pass-away. Human right violations, insurgency, terrorism, ethnic violence and frequent religious conflicts can also be attributed to this massive migration from Africa to Europe.

It has been reported by Germen Institute of Global and Area Studies that African migration to Europe is as a result of socio-economic changes over the decades. According to the report, from 1993 to 2003 African states became a conflict zone which dramatically increased the number of refugees. The report, however, revealed that the populations of 27 out 53 African states have suffered from violent conflicts and related. The report also figures out the proportion of these African refugees which constitute global average to about one third of the global refugee population (Kohnert, 2007). In another research, finding suggest that the vast majority of refugees and migrants, including those coming from Sudan and the Horn of Africa, enter Libya illegally or in fear of being illegal due to the lack of clarity over their legal status in the country. As a result, they fear being caught by 
the police and detained or sent back to their countries of origin. This irregular status forces them to continue to resort to smugglers even when not crossing an international border (Hamood, 2006).

According to another report in the last two decades Northern Africa developed into a transit region for Sub-Saharan migrants. The new migration pattern, its policy response by the Maghreb- and European states, as well as its negative 'side effects' on the migrants concerned, have been analysed. The actual number of Sub-Saharan migrants living 'in transit' in Northern Africa is difficult to estimate. But from the TRT World in a program 'The Newsmakers' it was reported that over 119,310 refugees arrived by sea from Libya in 2017 and 181,000 refugees or migrants entered Italy in 2018 through Libya, also 2,832 people died on their way to Italy in 2017 (Emma, 2018). Most of them are irregulars, 'without papers', mostly living as outcasts under miserable conditions. (Kohnert, 2007; Hamood, 2006). It has been estimated that over 10,000 migrants in 2018 are expected to evacuate from Libya and most of these migrants go through slave-labour (africannews, 2017).

\section{The Death of Gadhafi}

With the death of Gadhafi and the collapse of his regime, Libya became an unstable state with numerous channels and wings of rebels who conquer their terrain. This insecurity and disunity among the larger various ethnic tribes in Libya led to the loss of control by the current government to checkmate the activities of those rebels. These security and financial collapse in Libya no doubt brought a boom in trafficking and smuggling of persons and the emergence of Modern Slavery in Africa. Libya served as a transit for those migrants or traffickers who want to reach Europe.

\section{Nigeria as a Reference}

Nigeria is among the countries where its citizen becomes victims of circumstances of migration process to Europe. The reasons for this unprecedented prelude was as a result of many factors that include the high level of poverty, corruption pondering, and bad leadership by the previous administrations who failed to provide basic needs which would have transformed the standard living of the ordinary man. Since the country's return to political dispensation in 1999 the political atmosphere was not favouring an ordinary citizen because the available resources were not properly managed effectively. The decaying institutions and infrastructures have not been given adequate attention due to lack of political will and direction. The country is bedeviled with all sorts of social milieu including ethnic conflicts, political upheavals, religious cleansing, armed robbery, kidnapping and insurgency among others. Billions of dollars were syphoned and stashed in foreign banks.

These factors are among others which create an avenue with which Nigerians line-up themselves and embark on this dangerous journey to Europe. Travelling to Europe through illegal means is not a new phenomenon in the history of Nigeria. For long a lot of people 
already made their fortune successfully and the reason behind this blindfolded massive trooping to Europe by Nigerians was simply seeking for greener pastures. One of the states in the country that was seriously affected who have the dream of reaching Europe at all costs is Edo State in the south-south region of Nigeria. In fact it is a pride of every family to have sent someone to Europe that was why the family can sell all what they possessed just to fulfill the dream of their sons and daughters, because they know when they succeed, the lost belonging could be replaced within the shortest time possible. However, the dream of becoming rich and having better living standard end up in a nightmare to many of them (DailyTrust, 2017). Many of them going to Europe is not about apparent poverty or devastating conflict that drove them to travel to Europe but only anticipation and dreaming of getting rich overnight.

Human trafficking was an old institution among Nigerians and it provided riches to some other citizens who saw it as a lucrative business. These traffickers enjoyed the mode of business for long undisturbed, uninterrupted from all angle because they got maximum cooperation from the society and other security agencies for smoothness and sustainability of the trade. Why it becomes a subject of discourse today both in social and media agencies is because it changed to another perspective that of slavery.

\section{Who is to Blame?}

This is a simple question which is difficult to give direct answer considering unrealistic aspect in both parties involved. One direct answer to this question is punched at some African states who failed to do the right thing at the right time. The fact is that if the right thing is done this unprecedented challenge would not have been a matter of concern.

\section{African Leadership and lack of Good Governance a share of the Blame}

Ever since the beginning of modern African history in $20^{\text {th }}$ century the preludes are rapidly in dynamic. So many challenges blocked ways to African modern development and in the forefront is the issue of leadership and good governance. Leadership in some parts of African countries becomes a 'taste of honey' whose sweetness on the tongue changed perspective. African leaders are solely reliable on foreign aids for them to achieve desired development on their homeland. For how long these aids will continue to persist and be relied on? When will African leaders rethink on this unrealistic dependency? The better they got the answers to these questions the earlier they realized its high time Africans should depend on the available resources they have at their disposal to manage them.

It has been noted that the post-colonial states seems to have been planted with political instabilities by the colonialists. Instabilities all over the continent to the extent that there is no country in Africa where there is no one such political upheaval or another, galvanized the whole by communal, ethnicity or religious conflict or some other kind of disintegration. No matter their ideological learning, geographical location, period of their accession to 
independence, African countries are moving away completely too different trajectories from those anticipated at the beginning (Yandaki, 2015).

West African states on their part failed to do well in providing dividends of democracy to the masses. No viable projects to address the dilapidated infrastructure to curtail the economic opportunity. Unemployment is yet to be addressed properly so as to reduce restiveness among the teeming youths in the countries. Corruption has over taken in some governance affairs. Political upheaval and ethnic conflicts became operational in some occasions. Insecurity has threatened the existence of individual as an entity in his home country. The extreme poverty surrounding the masses in all ramifications left people to look for greener pastures.

Leadership in Africa is more concentrated on achieving national unity and political stability rather than economic development. The formation of continental body known as 'Organization of African Union' (O.A.U) which later metamorphoses into 'African Union' together with other existing regional bodies like the 'Economic Community of West African States' and 'East African Community' among others. The core objectives of their formation did not bring about much desire expectation considering varieties of conflicts bedeviling some part of the continent (Yandaki, 2015).

Even the so called economic integration of West African countries intended to strategize the economy for regional development failed to achieve its objectives, because even the regional monetary policy which aimed at providing one unity of West African single currency for boosting regional economy remained unrealistic. The reason behind this could be issue of dichotomy among African states (i.e. Francophone versus Anglophone) factors which both British and France seem it's against their monetization policy.

\section{European Foreign Economy Policy Fortified Migration Pressure from Africa}

On the European side, they have their share of blame. This has been noted during a joint European -African Union Migration Summit in Tripoli where they promised to take decisive and pro-active decision on the increased number of migrants, by a significant increase in aid to boost development to most affected West and North African countries more especially targeted on potential migrant populations. They, however, collectively decided to allocate the sum of $£ 40 \mathrm{~m}$ in order to revamp and create job opportunities in Africa (Union E. U.-A., 2006). But the central argument here is that, for how long will African countries depend on foreign aids before they could do things on their own? How many aids were given to some African countries but yet they failed to stimulate economic growth? Does this aid aim at revamping industrialization in Sub-Saharan Africa states? How benefited is it to the economy?

The answer to these questions is apparently no. This is because foreign aids do not build economic sustainability on sub-Saharan African states rather strengthened the security challenge to the benefit of European countries' security protection. In this regards foreign 
aids and trade policy do not salvage West African predicament economic hardship, it only addresses some other sectors. Thus, studies published by the World Bank, International organizations, NGOs and others repeatedly blame the European foreign aids and trade policies contributory to a significant extent and such reduce the income-earning possibilities of West African producers, in pursuit of the commercial interest of the European Union member states and to the detriment of development in Sub-Saharan Africa (Kohnert, 2007; Hamood, 2006).

It is beyond dispute that European economic policy is not favouring African economy directly. This is due to monopolization by the multi-national corporations which dominated the economic affairs of African states. It carried away manpower and labour whether directly or indirectly. International currency exchange, global trade and market pattern, politics of market, balance of trade, World Bank and International monitoring funds (IMF) are not stimulating African states economies.

\section{Strengthen Security Measures and Preventive Measures on African Migration to Europe is another share of blame}

The European Union is more concerned with their security strategic planning neglecting the actual root of the matter which if properly addressed, the situation on the ground could not have been worsening as it is today. From the report by the Join Migration and Development Conference at Rabat in Morocco with the attendance of over 30 representing African and European States. The outcome of the conference underlines the followings:

Those African partners accepted in principle the demand of their European colleagues for a more active involvement in the close supervision and prevention of irregular migration ('Action Plan of Rabat'). However it was agreed upon that stepping up border controls both at land and at sea would not suffice. New ways to open up legal ways of temporary or 'circular' migration and development of employment opportunities in the transit countries and countries of origin was considered to be a necessary supplement" (Rebat, 2006).

Again at the European Union Submit, the vice president Franco Frattini offered the following recommendations

That quota system of legal immigration adapted to the specific needs of each European Union member country. In the meantime, the implementation of other more subtle proposals of the European Commission's 'Global Approach on Migration' was accelerated, like the creation of job-recruiting centres for temporary African migrants in their home countries, co-financed by the EU and interested member states" (Tripoli, 2006). 
From another study on European Union project, a pilot project came out with the following results:

\begin{abstract}
Project in Mali was under construction, similar centres were planned for Senegal, Ghana and Mauritania. Their aim was to match the European demand for cheap labour, notably in Spain, Italy and France, in sectors like agriculture, building or cleaning, to the corresponding offer of suited African job seekers. Initially the job centres will be restricted to the capital, but later on regional offices in outlying towns or villages, where most migrants start their journey are envisaged. However, these plans were strongly opposed by right wing EU politicians, notably in Poland and other East-European member states, like Slovakia and Lithuania - as well as Romania and Bulgaria, which recently joined the EU. They argued that it would be difficult to understand for millions their voters, who would be happy to have low-skilled jobs in agriculture and other sectors within the EU, why they could not work freely in all EU member states, whereas millions of Euro would be spend on African immigrants (Union E. , 2007)
\end{abstract}

\title{
On the Part of Nigeria
}

Ever since the country returned to democracy, the polity is not in a proper direction considering the military rule which over stayed for more than sixteen years which contribute some obstacles in democratization in the country. The booming oil which is supposed to be a blessing is not as expected. Most of the grey areas that need to be resolved and put the economy in a stable direction are not possibilities. Although previous governments and the current one have waged campaigns against corruption, good governance and accountability in order to check mate poverty which led to this massive and dangerous migration to Europe. The security in the country in the past and at present is in a state of critical situation to extend that piracy, bunkering, insurgency and terrorism posed threats to the national integrity.

The current administration of President Muhammadu Buhari is doing its best in addressing the above mentioned peculiar challenges. The state of security is gradually improving; the fight against corruption is giving a positive result. The economy is stabilizing as the country has just come out from recession and the issue of migration and trafficking government had taken decisive measures and action to curtail the syndrome by setting up Rescue Mission Committee under the minister for foreign affairs to evacuate thousands of Nigerian refugees and traffickers in Libya and over 10,000 migrants were evacuated from Libya to Nigeria from 2017. The Nigerian government vows to prosecute human traffickers giving those victims entrepreneurship skills to start a new life.

\section{Conclusion}


Africanstates have come a long way suffering from different dislocations that is from shackles of colonialism to the total freedom of self-sovereignty but still some states are in the bondage of bad governance, corruption, political crises, ethnic cleansing, insurgency, terrorism and above all an old train metamorphoses into modern train, that is migration to Europe by Africans turned into slavery. The above issues of who is to blame need to be critically looked into and properly addressed by all the stakeholders.

\section{Reference}

Afolalu, R. O. (2000). History of Africa Since 1800. Ibadan: Onibonjo.

Africannews. (2017). The Libyan Migrant. africannews.

Ake, C. (2008). A political Economy of Africa. England: Longman Group.

Ayandele, B. O.-C. (1978). The Making of Modern Africa to The Late Nineteenth Century to the Present Day. London: Hong Kong Printing Press.

Crowder, M. (1978). West Africa Under Colonial Rule. London: London.ZDailyTrust. (2017). Journey to Libya. Abuja: Daily Trust.

Emma, B. (2018, August 01). Modern Slavery in Africa. (Imran, Interviewer)

Hamood, S. (2006). AFRICAN TRANSIT MIGRATION THROUGH. Cairo: Nezar Mosa Noreen.

Hance, W. (1970). Population, Migration and Urbanization in Africa. New York: Columbia University Press.

Jackson, J. (. (1964). Migration, Socio-logical Service. Cambridge: Cambridge.

Joshua, S. (2003). International Relations Fifth Edition. India: Person Education Ltd.

Kohnert, D. (2007). German Institute of Global and Area Studies Working Paper. German: Hamburg.

Onwubiko, K. (1985). School Certificate History of West Africa 1800- Present Day. Oweri: Africana-Fep Publishers Limited.

Rebat. (2006). Joint Migration and Development Conference. Morocco.

Rodney, W. (1972). How Europe Underdeveloped Africa. London: London.

Ryder, A. (2001). The Trans-Atlantic Slave Trade. In O. I. (edit), Groundwork of Nigerian History (p. 236). Ibadan: Heinemann Education Books .

Salami, E. (2000). The Power of The Poor. Sokoto: University Press.

Shehu, H. a. (2016). Contemporary History and Politics in Nigeria. Sokoto: Hoseni print.

Smith, A. (1988). Selected Writings: Centre for Historical Research. Zaria: Gaskiya Corporation Limited. 
Tripoli. (2006). Tripoli Summit. Tripoli.

Union, E. (2007). European Union Pilot Project. Mali.

Union, E. U.-A. (2006). European Union-African Union Migration Summit. Tripoli.

Yandaki, A. (2015). The State in Africa A critical Study in Historiography and Political Philosophy. Zaria: Gaskiya Corporation Limited. 